\title{
Evaluation of Tourist Activities and Destination Attraction Capacity Using Geotags
}

\author{
Vladimir Sergeevich TIKUNOV1, Vitalii Semenovich BELOZEROV2, \\ Stanislav Olegovich ANTIPOV2 \\ 1 Faculty of Geography, Lomonosov Moscow State University \\ vstikunov@yandex.ru \\ 2 Department of Socio-Economic Geography, Geoinformatics and Tourism, North-Caucasus Federal University \\ vsbelozerov@yandex.ru, antistas@yandex.ru
}

\begin{abstract}
Tourist location data accessible through social networks is a new source of information which is opening up great opportunities for studying tourism activities. We used tourist geotags from the VKontakte social network to evaluate the attractiveness of tourist destinations around the Caucasian Mineral Waters. Based on the data received from the public profiles of tourists publishing geotags, we analyzed their gender- and age-related structure, seasonal preferences, and geographic origins. The resort of Pyatigorsk was used as a case study to develop a classification of recreational areas for local people and tourists.

Women prevailed among those displaying their photos $-64.7 \%$. The two major seasons for attaching photos were spring and summer $-64.8 \%$ of the photos. The specific feature of the Caucasian Mineral Waters viewed as a tourist destination implied the prevalence of intraregional geotags over interregional ones. The major interregional tourist flow came from the cities of Moscow, St. Petersburg, Rostov-on-Don, and Krasnodar. The geotags on photos, therefore, may be used as an alternative source of information when evaluating the tourist activity and attractiveness of these destinations.
\end{abstract}

Keywords: Geotagged photos, geographic information analysis, tourism activities, tourist destination, attraction capacity

\section{Introduction}

The component-based approach is typically used to evaluate the attraction capacity of tourist objects. Each significant factor (landscape features, flora, certain natural phenomena) is evaluated on a scale (Dirin, Popov 2010). Points are totalled to obtain an integral value. Social surveys are also used, particularly questionnaires. In most cases, these questionnaires comprise three sections: details concerning the respondent, a list of the most attractive sites, and the attractiveness of individual visible elements of the landscape (Motoshina, Vdovyuk 2012).

Since these methods of attractiveness evaluation are costly and time-consuming when it comes to global research, there is obviously a need for alternative approaches. Location-based services (LBS) have begun to develop widely, including in the areas of recreation and tourism. At first, they were in the form of applications, but were then rapidly transformed into specialized platforms. The features of LBS services in various fields of application are described in (Cao et al. 2010; Okuyama, Yanai 2013; García-Palomares et al. 2015; Memon et al. 2015; Korakakis et al. 2016).

Nowadays, most mobile phones feature a digital camera and GPS-receiver which allow photographs to be tagged. Many tourists display photos taken on their travels on social networks. Platforms like Facebook, Instagram, Flickr, VKontakte and others offer access to these data and have become an indispensable source of statistical information for research, including in the field of tourism.

Kádár and Gede, for example, used geotagged photos of Budapest to show the most popular tourists sites (Kádár, Gede 2013). Of particular note is a study focusing on analyzing the spatiotemporal distribution of tourist photos in a rural area of South Korea. The authors of this study detected peaks of tourist activity in certain seasons and found a link between the number of tourist pictures and distance from major cities (Vu et al. 2015). They also investigated the respective movements of Western and Asian tourists, which helped identify differences in preferences between sites that were popular with the two groups.

KiG No. 32, Vol. 18, 2019, https://doi.org/10.32909/kg.18.32.3 


\title{
Procjena turističkih aktivnosti i kapaciteta privlačnosti različitih odredišta primjenom geooznaka
}

\author{
Vladimir Sergejevič TIKUNOV1', Vitalij Semjenovič BELOZEROV², Stanislav Olegovič ANTIPOV2 \\ 1 Geografski fakultet, Moskovsko Državno Sveučilište Lomonosova \\ vstikunov@yandex.ru \\ 2 Odjel društveno-ekonomske geografije, Geoinformatika i turizam, Sjeverno-kavkasko federalno sveučilište \\ vsbelozerov@yandex.ru, antistas@yandex.ru
}

\footnotetext{
Članak je predan na engleskom jeziku. Na hrvatski ga je preveo V. Lapaine. The paper was submitted in English. It was translated into Croatian by V. Lapaine.
}

Sažetak: Podatci o turističkim odredištima dostupni putem društvenih mreža nov su izvor informacija koji otvara velike mogućnosti proučavanja turističkih aktivnosti. Primjenom turističkih geooznaka iz društvene mreže VKontakte procijenili smo privlačnost turističkih odredišta oko Kavkaskih mineralnih voda. Na temelju podataka iz javnih profila turista koji objavljuju geooznake analizirali smo njihovu spolnu i dobnu strukturu, preferencije vezane uz godišnja doba te geografsko podrijetlo. Na primjeru odmarališta Pjatigorsk razvili smo klasifikaciju područja za rekreaciju za mjesno stanovništvo i turiste.

Među osobama koje prikazuju svoje fotografije prevladavaju žene (64,7\%). Godišnja doba u kojima se objavljuje najveći broj fotografija su proljeće i ljeto ( $64,8 \%$ fotografija). Na turističkom odredištu Kavkaskih mineralnih voda geooznake unutar regije prevladavaju nad geooznakama iz drugih regija. Većina turista iz drugih regija dolazi iz Moskve, Sankt Peterburga, Rostova na Donu i Krasnodara. Stoga geooznake na fotografijama možemo primijeniti kao drugi izvor informacija za procjenu turističkih aktivnosti i privlačnosti tih odredišta.

Ključne riječi: fotografije s geooznakama, analiza geoinformacija, turističke aktivnosti, turistička odredišta, kapacitet privlačnosti

\section{Uvod}

Za procjenu kapaciteta privlačnosti turističkih odredišta obično se primjenjuje pristup utemeljen na komponentama. Svaki se važan čimbenik (obilježja pejzaža, bilje, određene prirodne pojave) procjenjuje na ljestvici (Dirin, Popov 2010) i svi se bodovi zbrajaju. Primjenjuju se i anketni upitnici koji se u većini slučajeva sastoje od triju dijelova: detalja koji se odnose na sudionike istraživanja, popisa najprivlačnijih odredišta i privlačnosti pojedinih elemenata pejzaža (Motoshina, Vdovyuk 2012).

S obzirom na to da su navedene metode procjene privlačnosti skupe i vremenski zahtjevne kad je riječ o globalnom istraživanju, jasna je potreba za drugim pristupima. Usluge koje se temelje na položaju (location-based services - LBS) razvijaju se velikom brzinom pa i u područjima rekreacije i turizma. Prvo su to bile aplikacije koje su se ubrzo pretvorile u specijalizirane platforme. Obilježja usluga koje se temelje na položaju u različitim područjima primjene opisali su Cao i dr. (2010), Okuyama i Yanai (2013), García-Palomares i dr. (2015), Memon i dr. (2015), Korakakis i dr. (2016).

Većina suvremenih mobilnih uređaja sadrži digitalnu kameru i prijemnik GPS-a koji omogućuju stavljanje oznaka na fotografije. Mnogi turisti na društvenim mrežama objavljuju fotografije sa svojih putovanja. Platforme kao što su Facebook, Instagram, Flickr, VKontakte i druge omogućuju pristup tim podatcima i postali su neizbježan izvor statističkih informacija za istraživanja, uključujući i područje turizma.

Tako su Kádár i Gede analizirali fotografije Budimpešte $s$ geooznakama kako bi utvrdili najpopularnija turistička mjesta (Kádár, Gede 2013). Posebno je 
Sun, Fan and other researchers analyzed the location of hotels in Vienna preferred by tourists depending on the season (Sun et al. 2013).

The main sources for obtaining photo geotags in most studies were Flickr and Panaramio. Platforms like Instagram and Facebook require user consent for data processing. However, Flickr has 'only' 87 million users, which is rather modest compared to other social networks. Facebook boasted of between 650 million and 1 billion people in 2016; Qzone (China) has 640 million users, with Instagram accounting for another 500 million.

When researching recreational activities through the geotagging method, it is hard to distinguish between geotags published by locals and those published by tourists. To resolve this issue, a major criterion was the interval between the first and last embedding of a geotag in the destination (Girardin et al. 2008). If the interval was under five days, then the user was assumed to be a tourist rather than a local.

In our study, geotagged information was obtained from the VKontakte social network, which is the most popular one in Russia. User numbers are around 380 million, with 80 million visiting the site every day. This is a much wider coverage than Flickr. Another important advantage of this social network is the possibility of using the data in user profiles; gender, age, place of residence and interests. This allowed us to identify the categories of users who downloaded geotags, whether tourists or local residents.

In addition to comparing the number of published geotags, this approach allowed us to conduct a spatio-temporal analysis of tourist flows, identifying their geographical origins, their preferences according to different age and gender groups, and differences in their behaviour.

The purpose of this study was to evaluate the attractiveness of tourist destinations and sites at the Caucasian Mineral Waters through geotagged photos in the VKontakte social network, and to analyze the geography, seasonal dependence and gender and age structure of the tourist flows.

\section{Data Source and Methods}

The number of geotagged photos published in the VKontakte social network forms a large data set. Over 600 geotags are uploaded daily from the resort area of Pyatogirsk alone, while the area of the Caucasian Mineral Waters accounts for two to three thousand geotags per day.

In order to automate data collection, we developed a software product to obtain information on users publishing geotags in VKontakte (Figure 1). The software also offered an option for exporting the obtained data to geo-information systems.

Storage, spatial-temporal analysis and visualization of geotags were performed using ArcGISPro version 1.3.0. It supports working with big data, which was an important factor when choosing the GIS package.

A multiscale approach was adopted which allowed us to consider not only large destinations, but also individual tourist sites. The following territorial levels were identified within the multiscale approach

- the Caucasian Mineral Waters

- residential areas - the cities of Pyatigorskresid ential areas - the cities of Pyatigorsk, Zhelezno vodsk, Yessentuki and Kislovodsk

- tourist-recreation zones in resort cities

- tourist sites

As a rule, urban areas in resorts are divided into functional zones. Some are used by local residents for recreation, while others are popular with tourists. To identify such zones in Pyatigorsk, we used the Hot Spot Analysis Tool (Getis-OrdGi *). Since this tool supports work with numeric values only, we had to convert textual information to numeric. Users residing in Pyatigorsk were assigned a value of 1 within the geodatabase, and visitors were assigned a value of 2 .

The use of this tool also implied defining a null hypothesis. In our case, the null hypothesis was that the geotags embedded in photos by local residents and tourists were distributed in a random (chaotic) manner.

\section{Results and Discussion}

For the last hundred years, the area of the Caucasian Mineral Waters has been a tourist attraction. According to statistics provided by the Ministry of Culture of Stavropol Region, about 1.3 million tourists visited the Caucasian Mineral Waters in 2015 (Sorokina 2017). At the same time, official statistics contain no data on the geographical origin of incoming tourists, their age or gender, and do not include seasonal features. Most of these data can be obtained through the software.

As the study showed, between 30 September 2015 and 30 September 2016, 103372 tourist photo geotags were uploaded in the Caucasian Mineral Waters area. An analysis of the database at the level of the Caucasian Mineral Waters cities revealed that most of the tags related to Pyatigorsk (49 599), followed by Kislovodsk, Yessentuki, and Zheleznovodsk (Figure 2).

The attractiveness of inner urban areas and tourist facilities also revealed a significant difference. At the level of tourist attractions, the Kislovodsk Resort

KiG No. 32, Vol. 18, 2019, https://doi.org/10.32909/kg.18.32.3 - - 


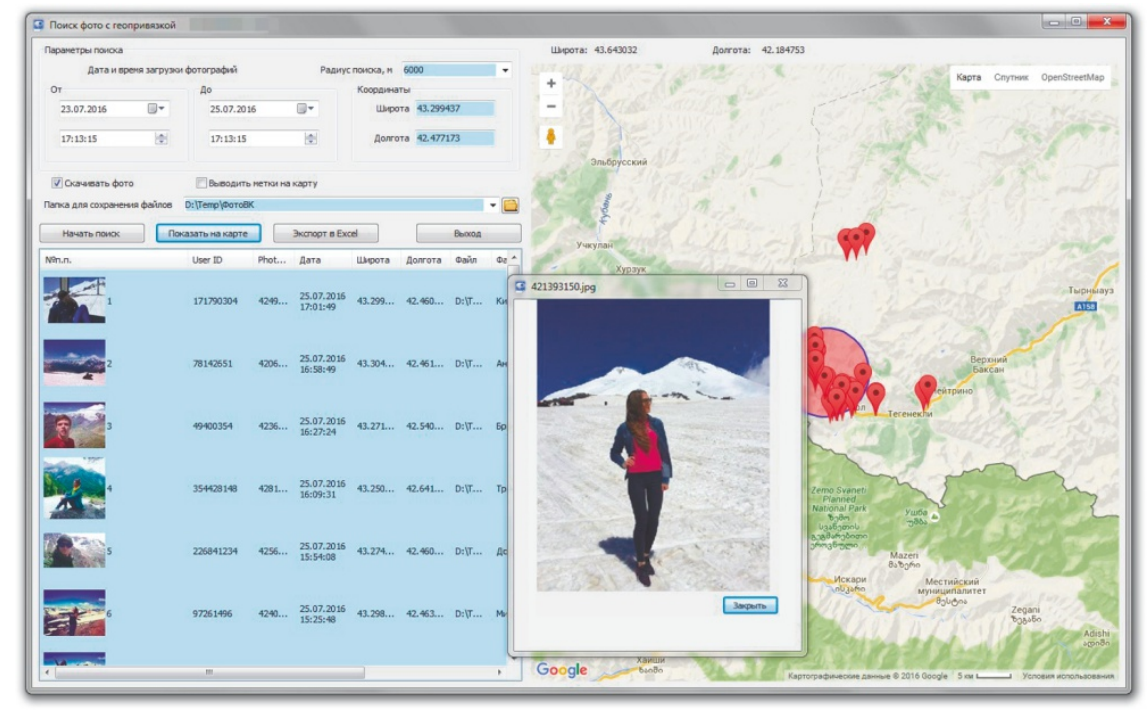

Slika 1. Program za pretraživanje geooznaka s fotografija.

Fig. 1 Programme for photo geotag search.

zanimljivo istraživanje usmjereno na analiziranje prostorno-vremenske raspodjele turističkih fotografija $\mathrm{u}$ ruralnom području u Sjevernoj Koreji. Autori istraživanja utvrdili su najveću turističku aktivnost $u$ određenim godišnjim dobima i pronašli povezanost između broja turističkih fotografija i udaljenosti od velikih gradova (Vu i dr. 2015). Također su istražili kretanje zapadnjačkih i azijskih turista, što je pomoglo pri utvrđivanju razlika u preferencijama tih dviju skupina.

Sun, Fan i drugi istraživači analizirali su položaje hotela u Beču koje turisti preferiraju ovisno o godišnjem dobu (Sun i dr. 2013).

Glavni izvori geooznaka na fotografijama $u$ većini istraživanja bili su Flickr i Panoramio. Platforme kao što su Instagram i Facebook zahtijevaju privolu korisnika za obradu informacija. Međutim, Flickr ima „samo“ 87 milijuna korisnika, što je prilično malo u odnosu na druge društvene mreže. Facebook se 2016. hvalio da ima između 650 milijuna i 1 milijarde korisnika, Qzone (Kina) ima 640 milijuna korisnika, a Instagram 500 milijuna.

Prilikom istraživanja rekreacijskih aktivnosti upotrebom geooznaka nije moguće razlučiti koje geooznake objavljuje mjesno stanovništvo, a koje objavljuju turisti. Taj je problem moguće riješiti tako da se utvrdi vremenska razlika između prve i posljednje geooznake na određenom odredištu (Girardin i dr. 2008). Ako je ta razlika manja od pet dana, pretpostavka je da je taj korisnik turist.

$\mathrm{U}$ našem smo istraživanju geooznake preuzeli s VKontakte, najpopularnije društvene mreže u Rusiji. Ona ima oko 380 milijuna korisnika, pri čemu otprilike 80 milijuna korisnika pristupi toj stranici svaki dan, što je mnogo više nego za društvenu mrežu Flickr. Druga važna prednost društvene mreže VKontakte jest mogućnost upotrebe podataka u korisničkim profilima - spol, dob, prebivalište i interesi. Mogli smo, stoga, utvrditi kategorije korisnika koji preuzimaju geooznake, bili oni turisti ili mjesno stanovništvo.

Osim što smo usporedili broj objavljenih geooznaka, navedenim smo pristupom mogli provesti i prostorno-vremensku analizu toka turista, utvrditi njihovo geografsko podrijetlo, preferencije s obzirom na dob i spol te razlike u ponašanju.

Svrha našeg istraživanja bila je procijeniti privlačnost različitih turističkih odredišta oko Kavkaskih mineralnih voda pomoću fotografija s geooznakama s društvene mreže VKontakte te analizirati geografiju, ovisnost o godišnjem dobu te strukturu toka turista prema spolu i dobi.

\section{Izvori podataka i metode}

Na društvenoj se mreži VKontakte objavljuje veliki broj fotografija s geooznakama. Svakoga se dana samo u području odmorišta Pjatigorsk objavi više od 600 geooznaka, dok za područje Kavkaskih mineralnih voda ta brojka premašuje dvije ili tri tisuće geooznaka dnevno.

Kako bismo automatizirali prikupljanje podataka, razvili smo softver koji preuzima informacije o korisnicima koji objavljuju geooznake na društvenoj mreži VKontakte (slika 1). Taj softver također omogućava izvoz dobivenih podataka u geoinformacijske sustave.

Pohrana, prostorno-vremenska analiza i vizualizacija geooznaka provedena je uz pomoć programa ArcGISPro, verzija 1.3.0. On omogućuje rad s velikom količinom podataka (big data), što nam je bio važan čimbenik. 


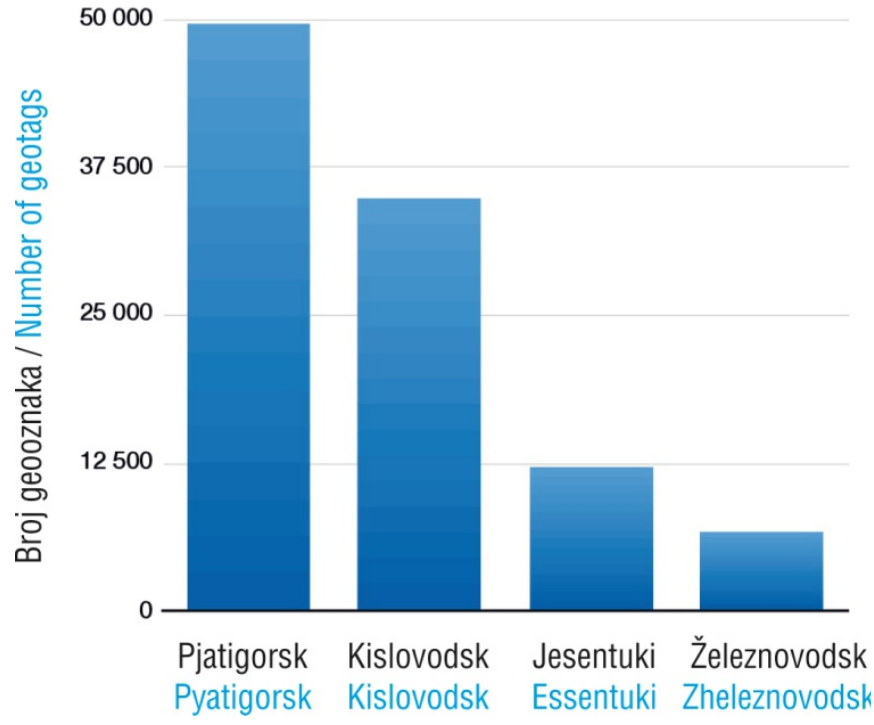

Fig. 2 Number of tourist photo geotags.

Slika 2. Broj turističkih geooznaka na fotografijama.

Park stood out with 24,460 geotags, while Pyatigorsk with Mashuk Mount accounted for 24,102 geotags.

Women prevailed among those publishing photos (64.7\%). This trend was seen throughout all the age groups. As for the general age structure of the tourist population, young people aged 18-39 predominated (72\% of photos) (Figure 3$)$.

Figure 4 shows the monthly dynamics of the geotags published. The main seasons for adding geotags, reflecting the peaks of the tourist inflow, were spring and summer, which accounted for $64.8 \%$ of all photos. Winter was not as attractive, with $15.9 \%$ (Figure 4).

Tourist flows represent actual demand and reveal great diversity. The tourist flow in the Caucasian Mineral Waters destination reveals a wide geographical coverage and involves people from 1,148 places all over Russia. According to an analysis of tourist geotags, four cities of origin stand out; Moscow, St. Petersburg, Rostov-onDon, and Krasnodar. These account for $39.6 \%$ of the total number of geotags. A number of cities on the River Volga and in central Russia were also detected (Figure 5).

The spatial distribution of the photos geotagged by local residents and tourists led to discussions on the internal territorial structure of a particular destination. The territorial structure of the resort of Pyatigorsk features certain parts which specialize in particular types of recreation and thus attract different categories of tourists (Figure 4).

As a result of the study, a cluster model was obtained for objects with high and low values, interpreted as follows:

1. Hot spots (highlighted in red) with a likelihood of $95 \%$ and $99 \%$ - clustering of geotags on photos by tourists.

2. Cold spots (highlighted in blue) with a likelihood of

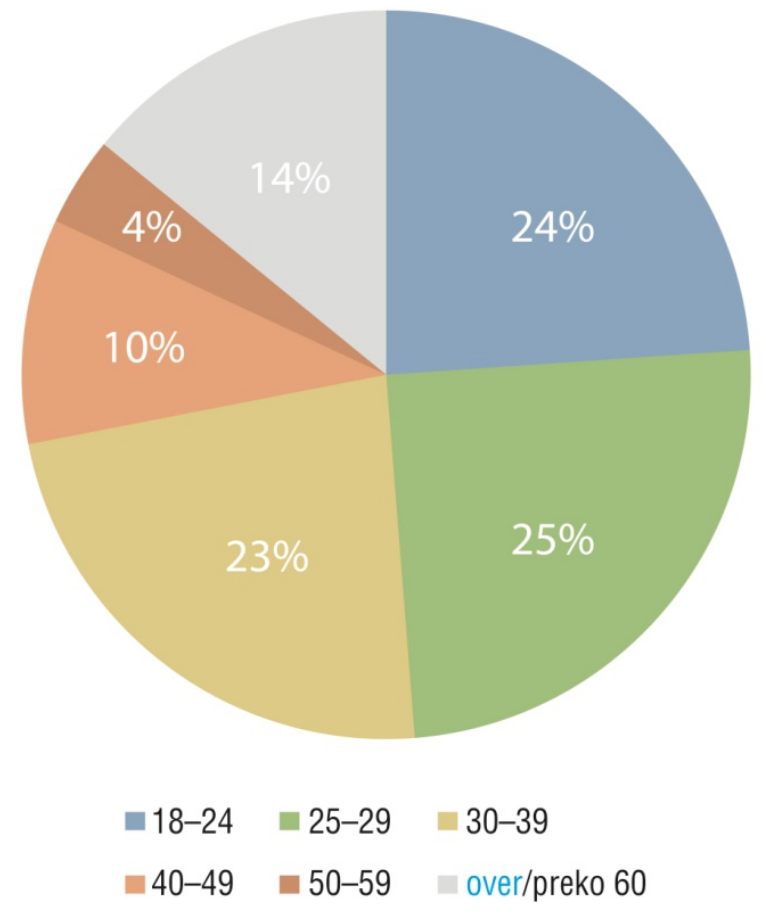

Fig. 3 Age structure of users publishing geotags.

Slika 3. Dobna struktura korisnika koji objavljuju geooznake.

$95 \%$ and $99 \%$ - clustering of geotags on photos by local residents.

3. Cold spots with a likelihood of $90 \%$ and hot spots of the same likelihood as well as spots of insignificant clustering (beige) - clustering of geotags on photos by local residents and tourists.

A specific feature concerning the geotag distribution on photos by locals was high clustering within the urban area (Figure 6). This distribution of recreational zones by locals is probably due to their better awareness of recreation areas, the capacity of such zones and their availability.

Depending on the type of recreational activities pursued by tourists, geotags helped identify two types of zones in Pyatigorsk (Table 1).

Type 1 - therapy and recreation tourism zones. These are used for preventive medical activities and health improvement as part of special recreational programmes. They are located in the urban spa area on the premises of spa-hotels and in close proximity to spring-rooms offering access to mineral waters.

Type 2 - culture tourism areas, which are typically popular with tourists when not engaged in therapy or recreational activities. Such zones are located in various places of interest (Love Gate, Site of Mikhail Lermontov's Duel, Lermontov Museum, The Downsink, Aeolian Harp and so on).

Based on the activities pursued by local residents, the recreational zones of Pyatigorsk could be divided into two types (Table 2):

KiG No. 32, Vol. 18, 2019, https://doi.org/10.32909/kg.18.32.3 


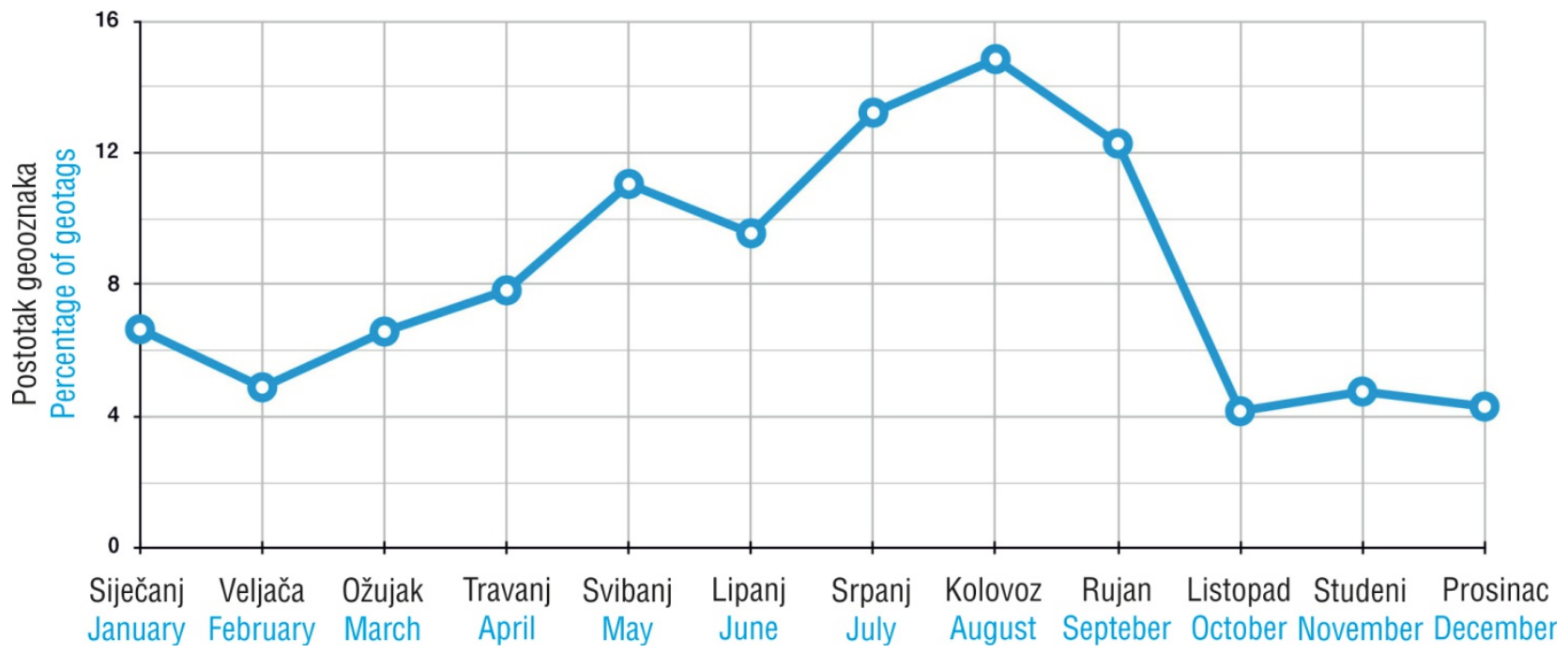

Slika 4. Raspodjela geooznaka po godišnjim dobima.

Fig. 4 Seasonal distribution for adding geotags.

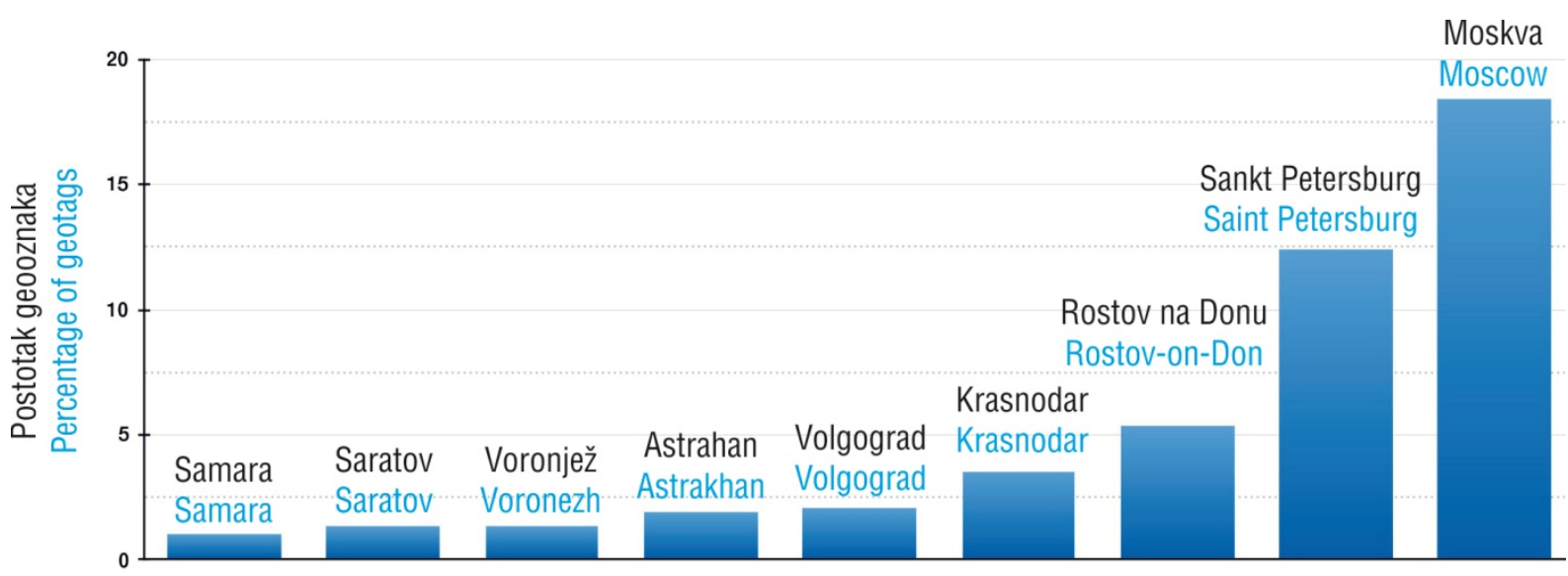

Slika 5. Geografski položaji turista koji su objavili fotografije s geooznakama.

Fig. 5 Geographical location of tourists who published geotags on photos.

Primijenili smo višeskalni pristup koji nam je omogućio da u obzir uzmemo velika odredišta, kao i pojedine turističke destinacije. Tim smo pristupom utvrdili sljedeće teritorijalne razine:

- Kavkaske mineralne vode

- stambena područja - gradovi Pjatigorsk, Železnovodsk, Jesentuki i Kislovodsk

- turističko-rekreacijska područja u gradovimaodmaralištima

- turistička mjesta.

U pravilu, urbana se područja u odmaralištima dijele na funkcionalne zone. Neke upotrebljava mjesno stanovništvo za rekreaciju, a druge su popularne među turistima. Kako bismo utvrdili takve zone u Pjatigorsku, primijenili smo Hot Spot Analysis Tool (Getis-OrdGi *). Budući da taj softver podržava samo rad s brojčanim vrijednostima, bilo je potrebno pretvoriti tekstualne informacije u brojčane. Korisnicima koji žive u Pjatigorsku dodijeljena je vrijednost 1 , a turistima vrijednost 2 .

Upotreba tog softvera također je podrazumijevala nul-hipotezu. U našem je slučaju nul-hipoteza da su geooznake ugrađene $u$ fotografije mjesnog stanovništva $i$ turista raspodijeljene na nasumičan (kaotičan) način.

\section{Rezultati i rasprava}

Područje Kavkaskih mineralnih voda u posljednjih je sto godina turistička atrakcija. Prema statističkim podatcima dobivenima od Ministarstva kulture regije Stavropol, to je područje u 2015. godini posjetilo oko 1,3 milijuna turista (Sorokina 2017). Službena statistika ne sadrži podatke o geografskom podrijetlu turista, 
Table 1 Types of tourist zones in Pyatigorsk.

Tablica 1. Tipovi turističkih područja u Pjatigorsku.

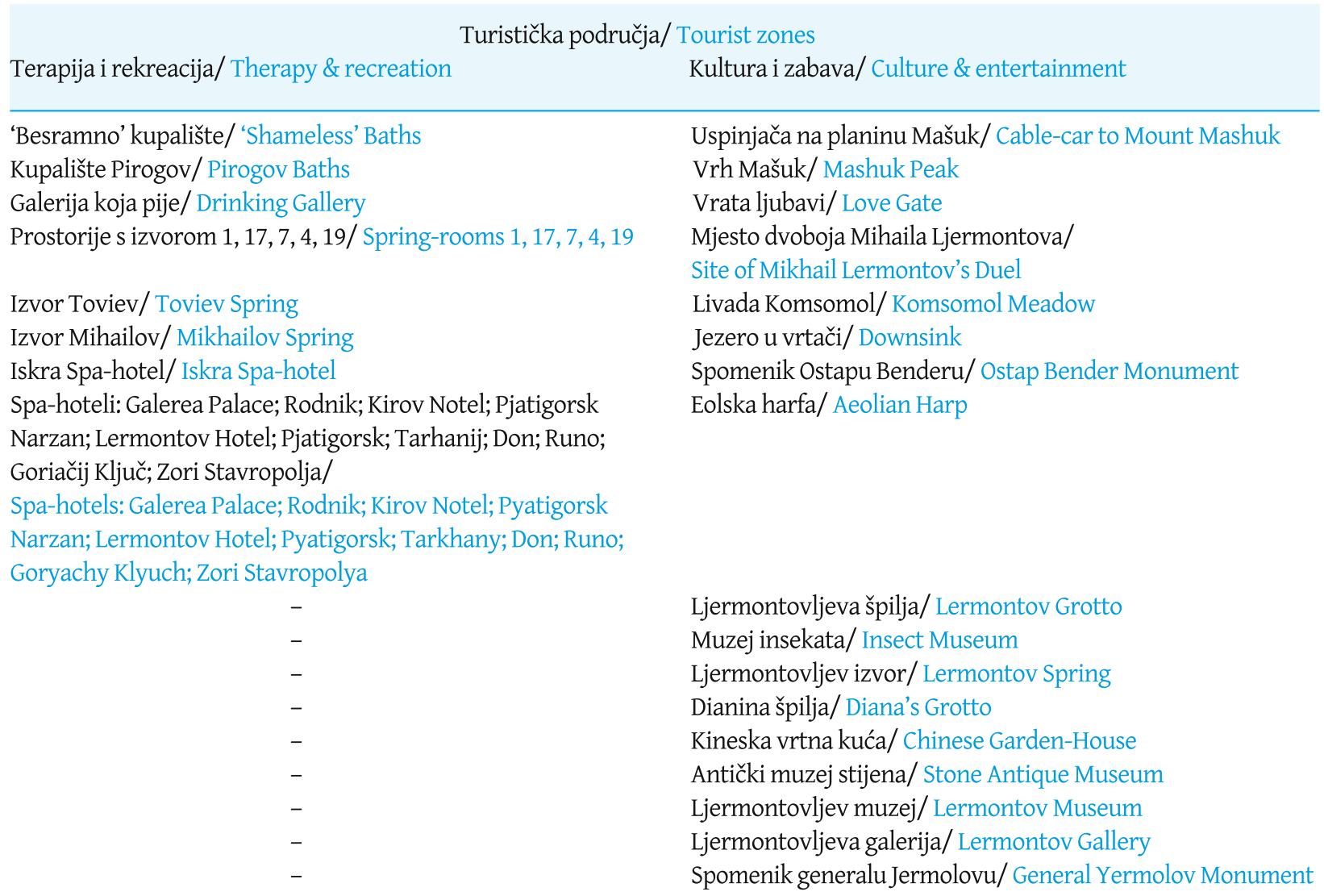

Table 2 Types of recreational zones in Pyatigorsk.

Tablica 2. Tipovi rekreacijskih područja u Pjatigorsku.

\begin{tabular}{ll} 
Zabava i rekreacija/ Entertainment \& recreation & $\begin{array}{l}\text { Rekreacijska područja/ Recreational zones } \\
\text { Šetališta/ Walking }\end{array}$ \\
\hline $\begin{array}{l}\text { Novopjatigorskoe jezero/ Lake Novopyatigorskoe } \\
\text { Kulturni i rekreacijski park Kirov/ Kirov Culture \& }\end{array}$ & $\begin{array}{l}\text { Lenjinov trg/ Lenin Square } \\
\text { Recreation Park }\end{array}$ \\
$\begin{array}{l}\text { Park Komsomol/ Komsomol Park } \\
\text { Terrenkur na planini Mašuk/ Terrenkur at Mount Mashuk }\end{array}$ & $\begin{array}{l}\text { Fontana koja pjeva/ Singing Fountain } \\
\text { Park Rodnik/ Rodnik Park }\end{array}$ \\
\hline
\end{tabular}

Type 1 - entertainment and recreational zones. These include entertainment infrastructure - attractions, zoos, playgrounds, etc. In the mornings (6:009:00) and evenings (18:00-21:00) these places are used for sports and recreational activities.

Type 2 - walking areas. They reveal a linear structure $500 \mathrm{~m}$ to $2 \mathrm{~km}$ long. Typically, the perimeter of the walking zones features recreational infrastructure - cafes, restaurants, clothes shops, and other boutiques. The popularity peak occurs during weekends and holidays, mostly in the warmer seasons.

The border between tourist and recreational zones is clear cut - the central part of Terrenkur around
Mashuk, Spassky Cathedral, Lermontov Garden Square, Lenin Monument and the Gate to Lermontov's duel site. Tourism and recreational zones have an equal correlation of geotags on photos displayed by local users and those from other places. These places of interest can be said to be equally attractive to both locals and visitors.

There are different factors that shape these types of zones. A major factor is access to public transport used by local residents and tourists. The tourist-recreational zone at Spassky Cathedral and Lermontov Garden Square, for instance, is within a five-minute walk of public transport stops connecting with the commuter belt around the area.

KiG No. 32, Vol. 18, 2019, https://doi.org/10.32909/kg.18.32.3 


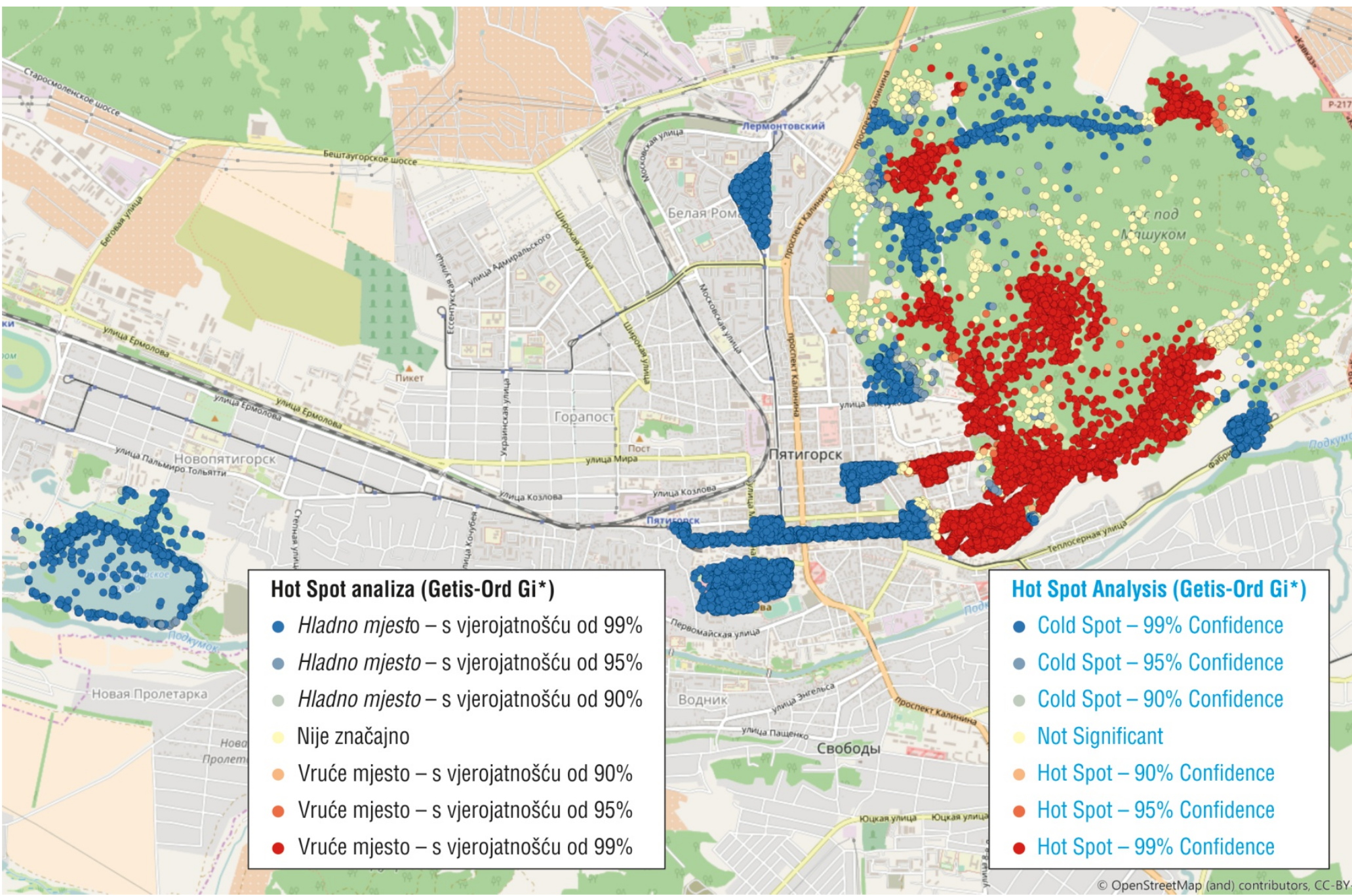

Fig. 6 Cluster concentration of geotags on photos displayed by local residents and tourists.

Slika 6. Grupiranje geooznaka na fotografijama koje su objavili mjesno stanovništvo i turisti.

njihovoj dobi i spolu te obilježjima godišnjih doba. Većinu je tih podataka moguće dobiti upotrebom softvera.

Rezultati pokazuju da je između 30. rujna 2015. i 30. rujna 2016. objavljeno 103372 geooznaka na fotografijama koje se odnose na područje Kavkaskih mineralnih voda. Analizom baze podataka na razini gradova Kavkaskih mineralnih voda utvrdili smo da se većina geooznaka odnosi na Pjatigorsk (49 599), zatim Kislovodsk, Jesentuki i Železnovodsk (slika 2).

Privlačnost unutarnjih urbanih područja i turističkih mjesta također je pokazala značajnu razliku. Među turističkim atrakcijama ističe se park-odmaralište Kislovodsk s 24460 geooznaka, dok se 24102 geooznaka odnosi na Pjatigorsk i planinu Mašuk.

Većinu fotografija objavile su žene (64,7\%). Taj je trend vidljiv u svim dobnim skupinama. Što se tiče opće strukture dobi turističke populacije, najviše je bilo mladih ljudi dobi 18-39 godina (72\% fotografija) (slika 3).

slika 4 pokazuje mjesečnu dinamiku objavljenih geooznaka. Glavna su godišnja doba u kojima se objavljuju geooznake, a što pokazuje vrhunac dolaska turista, proljeće i ljeto što obuhvaća $64,8 \%$ svih fotografija. Zima nije bila toliko atraktivna i samo 15,9\% fotografija je objavljeno zimi (slika 4).

Tok turista predstavlja potražnju i otkriva veliku različitost. Tok turista u području Kavkaskih mineralnih voda otkriva veliku geografsku pokrivenost i uključuje ljude iz 1148 mjesta iz cijele Rusije. Prema analizi turističkih geooznaka ističu se četiri grada: Moskva, Sankt Peterburg, Rostov na Donu i Krasnodar. Oni zajedno čine 39,6\% svih geooznaka. Također je primijećen velik broj gradova na rijeci Volgi i u središnjoj Rusiji (slika 5).

Prostorna raspodjela fotografija s geooznakama mjesnog stanovništva i turista dovodi do rasprave o unutarnjoj teritorijalnoj strukturi pojedinih odredišta. Teritorijalna struktura odmarališta Pjatigorsk sastoji se od pojedinih dijelova koji su specijalizirani za određene tipove rekreacije i stoga privlače različite kategorije turista (slika 4). 
Another factor is the diversity of tourism and recreational activities available within a single area. Here, mention should be made of Mount Mashuk, where layer-by-layer clustering of photo geotags can be seen. The top of the mountain and the Terrenkur area $1.5 \mathrm{~km}$ from the peak comprise a tourist area that presents wide landscape diversity and a well-developed infrastructure. Further on, the diversity is not so marked and the tourism area gives way to a tourism and recreational zone, and finally, to a recreational zone with several sports-recreational activities.

\section{Conclusion}

This study

- has shown that geotags displayed in social networks may be used as a source of data for a spatial-temporal analysis of tourist activity in tourist destinations at various territorial levels

- has helped identify differences in the attractiveness of the Caucasian Mineral Waters resort cities

- has helped identify inner-city destinations that are the most attractive to tourists and local residents.
This newly-developed approach allows information to be obtained about users via their social network profiles, through analyzing their gender and age structure, determining their geographical origin coverage and the seasonal features of tourist flows, as well as identifying the areas used by tourists and the local population for recreation.

The methodology proposed for evaluating the attractiveness of tourist destinations allowed us to conduct tourist and recreational zoning of the resort of Pyatigorsk, based on recreational activities, and helped identify four types of zones: cultural and educational, therapeutic and recreational, walking, and entertainment-recreational.

Through future research projects, we plan to establish a correlation between the tourist flow in the Caucasian Mineral Waters and the number of geotags published on the VKontakte social network, along with testing a geotagging-based methodology for evaluating tourist destinations in other areas, in Russia and abroad. This will undoubtedly contribute to the expansion of such resources as Bluetooth, the improvement of Wi-Fi services, and the development of ultra-wideband communication.

\section{References / Literatura}

Cao L, Luo J, Gallagher A, Jin X, Han J, Huang T S (2010) A world wide tourism recommendation system based on geotagged web photos, IEEE International Conference on Acoustics, Speech and Signal Processing, Dallas, TX, 2274-2277, doi: 10.1109/ICASSP.2010.5495905

Dirin D, Popov E (2010) Evaluation of landscape \& esthetic attractiveness of landscapes: methodological overview. Izvestiya Altaiskogo Gosudarstvennogo Universiteta. Barnaul: Federal State Budgetary Educational Institution for Higher Professional Education Altay State University, N4, 120-124

García-Palomares J C, Gutiérrez J, Mínguez C (2015) Identification of tourist hot spots based on social networks: A comparative analysis of European metropolises using photo-sharing services and GIS, Applied Geography, Vol. 63, 408-417, doi.org/10.1016/j.apgeog.2015.08.002

Girardin F, Fiore F D, Ratti C, Blat J (2008) Leveraging Explicitly Disclosed Location Information to Understand Tourist Dynamics: A Case Study. Journal of Location Based Services, N1(2), 41-56, http://dx.doi.org/10.1080/17489720802261138

Kadar D, Gede M (2013) Where Do Tourists Go? Visualizing and Analysing the Spatial Distribution of Geotagged Photography. Cartographica: The International Journal for Geographic Information and Geovisualization, 78-89, doi: 10.3138/carto.48.2.1839

Korakakis, M., Mylonas, P., Spyrou, E. (2016) Xenia: A context aware tour recommendation system based on social network metadata information, 11th International Workshop on Semantic and Social Media Adaptation and Personalization (SMAP), Thessaloniki, 59-64, doi: 10.1109/SMAP.2016.7753385

Memon I, Chen L, Majid A, Lv M, Hussain I, Chen G (2015) Travel Recommendation Using Geo-tagged Photos in Social Media for Tourist, Wireless Pers Commun 80, doi.org/10.1007/s11277014-2082-7

Motoshina A, Vdovyuk L (2012) Evaluation of esthetic features in landscapes of Tobolsky Rayon, Tyumen Area for recreational purposes. Geographic Newsletter. Perm: Federal State Budgetary Educational Institution for Higher Professional Education Perm State National Research University, N4(23), 21-31

Okuyama K, Yanai K (2013) A Travel Planning System Based on Travel Trajectories Extracted from a Large Number of Geotagged Photos on the Web. In: The Era of Interactive Media. Springer, New York, NY doi.org/10.1007/978-1-4614-3501-3_54

Sorokina N (2017) Stavropol region in numbers. Stavropolstat. https://goo.gl/uoRZ8f. Accessed 12 Dec 2017

Sun Y, Fan H, Helbich M, Zipf A (2013) Analyzing human activities through volunteered geographic information: Using Flickr to analyze spatial and temporal pattern of tourist accommodation. Progress in location-based services. Berlin Heidelberg: Springer, 489-502

Vu H Q, Li G, Law R, Ye B H (2015) Exploring the travel behaviors of inbound tourists to Hong Kong using geotagged photos. Tourism Management, N46, pp. 222-232, https://doi.org/10.1016/j.tourman.2014.07.003 
Rezultat istraživanja je model grupa za objekte s visokim i niskim vrijednostima, sa sljedećom interpretacijom:

1. Vruća mjesta (označena crvenom) s vjerojatnošću od 95\% i 99\% - grupiranje geooznaka na fotografijama turista

2. Hladna mjesta (označena plavom) s vjerojatnošću od 95\% i 99\% - grupiranje geooznaka na fotografijama mjesnog stanovništva

3. Hladna mjesta s vjerojatnošću od $90 \%$ i vruća mjesta jednake vjerojatnosti, kao i mjesta neznačajnog grupiranja (bež) - grupiranje geooznaka na fotografijama mjesnog stanovništva i turista.

Specifično obilježje koje se odnosi na raspodjelu geooznaka na fotografijama mjesnog stanovništva je veliko grupiranje unutar gradskih područja (slika 6). Takva se raspodjela rekreacijskih područja mjesnog stanovništva vjerojatno može objasniti njihovim boljim poznavanjem područja rekreacije, kapaciteta takvih područja i njihove dostupnosti.

Ovisno o vrsti rekreacije koju traže turisti, geooznakama se mogu utvrditi dva tipa područja u Pjatigorsku (Tablica 1).

Tip 1 - terapijska i rekreacijska turistička područja. Ta se područja primjenjuju za preventivne medicinske aktivnosti i poboljšanje zdravlja u sklopu posebnih rekreacijskih programa. Nalaze se $u$ urbanom spa području u sklopu hotela i blizu soba s pristupom izvorima mineralnih voda.

Tip 2 - kulturna turistička područja koja zanimaju turiste kada se ne bave terapijskim ili rekreacijskim aktivnostima. Takva se područja nalaze na različitim mjestima interesa (Vrata ljubavi, mjesto dvoboja Mihaila Ljermontova, Ljermontovljev muzej, Jezero u vrtači, Eolska harfa, itd.).

Prema aktivnostima koje zanimaju mjesno stanovništvo, rekreacijska područja u Pjatigorsku mogu se podijeliti na dva tipa (Tablica 2):

Tip 1 - zabavna i rekreacijska područja. Ona uključuju zabavnu infrastrukturu - atrakcije, zoološke vrtove, igrališta, itd. Ta se mjesta ujutro (6:00-9:00) i navečer (18:0021:00) upotrebljavaju za sportske i rekreacijske aktivnosti.

Tip 2 - šetališta. Linearne su strukture i duljine između $500 \mathrm{~m} \mathrm{i} 2 \mathrm{~km}$. U okviru šetališta obično se nalazi rekreacijska infrastruktura - kafići, restorani, trgovine odjećom i druge trgovine. Vrhunac je popularnosti u vrijeme vikenda i praznika, pogotovo tijekom toplijih godišnjih doba.

Granica između turističkih i rekreacijskih područja jasna je - središnji dio Terrenkura oko Mašuka, katedrala Spaskij, Ljermontovljev vrtni trg, spomenik Lenjinu i Vrata prema mjestu Ljermontovljevog dvoboja. Turistička i rekreacijska područja jednako su zanimljiva i mjesnom stanovništvu i posjetiteljima i imaju jednaku korelaciju geooznaka na fotografijama koje su objavili mjesno stanovništvo i turisti.

Navedene tipove područja oblikuju različiti čimbenici. Značajan je čimbenik pristup javnom prijevozu kojim se služe mjesno stanovništvo i turisti. Na primjer, turističkorekreacijsko područje kod katedrale Spaskij i Ljermontovljevog vrtnog trga nalazi se na pet minuta hoda od stajališta javnog prijevoza koji povezuje pojas oko toga područja.

Drugi je čimbenik raznolikost turističkih i rekreacijskih aktivnosti unutar određenog područja. Ovdje treba spomenuti planinu Mašuk gdje se može vidjeti grupiranje geooznaka na fotografijama sloj-po-sloj. Vrh planine i područje Terrenkur $1,5 \mathrm{~km}$ od vrha čine turističko područje koje ima veliku raznolikost pejzaža i dobro razvijenu infrastrukturu. Dalje raznolikost nije toliko velika i turistička područja prelaze u turističkorekreacijsko područje te naposljetku u rekreacijsko područje s nekoliko sportsko-rekreativnih aktivnosti.

\section{Zaključak}

Ovo je istraživanje pokazalo da se geooznake objavljene na društvenim mrežama mogu upotrijebiti kao izvor podataka za prostorno-vremensku analizu turističkih aktivnosti na turističkim odredištima različitih teritorijalnih razina. Pomoglo je utvrditi razlike u privlačnosti gradova-odmarališta pri Kavkaskim mineralnim vodama te područja unutar grada koja su najprivlačnija i turistima i mjesnom stanovništvu.

Takav novi pristup omogućuje dobivanje informacija o korisnicima putem njihovih profila na društvenim mrežama, analizu njihove spolne i dobne strukture, utvrđivanje njihovog geografskog podrijetla i toka turista ovisno o godišnjem dobu, kao i utvrđivanje područja kojima se turisti i mjesno stanovništvo služe za rekreaciju.

Metodologija predložena za procjenu privlačnosti turističkih odredišta omogućila nam je da na temelju rekreacijskih aktivnosti istražimo odmaralište Pjatigorsk i utvrdimo četiri tipa područja: kulturna i obrazovna, terapeutska i rekreacijska, hodališta te zabavno-rekreacijska.

U budućim istraživačkim projektima namjeravamo utvrditi povezanost između toka turista u Kavkaskim mineralnim vodama i broja geooznaka objavljenih na društvenoj mreži VKontakte, kao i isprobati metodologiju utemeljenu na geooznakama za procjenu turističkih odredišta na drugim područjima u Rusiji i inozemstvu. To će nedvojbeno pridonijeti širenju tehnologija kao što je Bluetooth, poboljšanju usluga bežičnog interneta i razvoju ultra-širokopojasne komunikacije. 